\title{
КОНСТИТУЦИОННОЕ ПРАВОСУДИЕ: ОТДЕЛЬНЫЕ ВОПРОСЫ СТАНОВЛЕНИЯ И РАЗВИТИЯ
}

\section{CONSTITUTIONAL JUSTICE: SELECTED ISSUES OF FORMATION AND DEVELOPMENT}

\section{A. Savastleev}

Summary. The implementation of constitutional justice in modern Russia is of particular importance. The study of historical aspects in the development of constitutional justice allows us to consider the previous experience, assess the current state of the issue, identify existing problems and predict the directions of further development. The subject of the research is presented by regulatory legal acts, provisions of legal doctrine and law enforcement practice on certain issues of the formation and development of constitutional justice in the Russian Federation.

The purpose of this work is to study individual issues of the formation and development of constitutional justice in the Russian Federation. The study used general methods of scientific knowledge and special legal methods. Scientific novelty lies in a generalized legal study of individual issues of the formation and development of constitutional justice in the Russian Federation, which is reflected in the results obtained, which can be used for educational, pedagogical and methodological purposes, as well as in theoretical understanding of topical issues in the field of improving the constitutional justice system.

Conclusions. In the course of the study, the concept of constitutional justice and the direction of its action, functional purpose was determined. The question of the periodization of the history of constitutional justice of the Russian Federation is touched upon, on the basis of which the characteristic features of the development of constitutional justice in the pre-revolutionary, Soviet and modern periods are considered. In connection with the abolition of the constitutional (statutory) courts of the constituent entities of the Russian Federation, it was concluded that it is necessary to improve the legislative basis for the mechanism of activity of constitutional (statutory) councils, determine the system of their powers, and the role in the implementation of regional constitutions and statutes.

Keywords: legal proceedings, constitutional justice, the Russian Federation, state, social values, history, development, formation, guarantees, mechanism, implementation.
Савастлеев Андрей Андреевич

Аспирант, Нижегородский институт управления филиал ФГБОУ ВО «Российская академия народного хозяйства и государственной службы при Президенте Российской Федерации» Daytona@konstantah.com

Аннотация. Осуществление конституционного правосудия в современной России представляет особое значение. Изучение исторических аспектов в развитии конституционного правосудия позволяет рассмотреть сложившийся ранее опыт, оценить современное состояние вопроса, определить существующие проблемы и спрогнозировать направления дальнейшего развития. Предмет исследования представлен нормативными правовыми актами, положениями юридической доктрины и правоприменительной практикой по отдельным вопросам становления и развития конституционного правосудия в Российской Федерации.

Цель работы — исследовать отдельные вопросы становления и развития конституционного правосудия Российской Федерации. В исследовании использованы общие методы научного познания и специальные юридические методы. Научная новизна заключается в обобщенном правовом исследовании отдельных вопросов становления и развития конституционного правосудия Российской Федерации, что нашло отражение в полученных результатах, которые могут быть использованы в учебно-педагогических и методических целях, а также при теоретическом осмыслении актуальных вопросов в сфере совершенствования системы конституционного правосудия.

Выводы. В ходе исследования определено понятие конституционного правосудия и направленности его действия, функционального предназначения. Затронут вопрос о периодизации истории конституционного правосудия Российской Федерации, на основании чего рассматриваются характерные черты развития конституционного правосудия в дореволюционный, советский и современный периоды. В связи с упразднением конституционных (уставных) судов субъектов РФ, сделан вывод 0 необходимости совершенствования законодательной основы для механизма деятельности конституционных (уставных) советов, определения системы их полномочий, роли в исполнении региональных конституций и уставов.

Ключевые слова: судопроизводство, конституционное правосудие, Российская Федерация, государство, общественные ценности, история, развитие, становление, гарантии, механизм, реализация. 


\section{Ввемение}

3 акрепление в положениях Конституции Российской Федерации (далее - Конституции РФ) основополагающих прав и свобод, подходов к организации государственной власти и местного самоуправления, а также иных важных положений, позволяет поддерживать систему основополагающих общественных ценностей, состояние правопорядка в стране. Положения Конституции РФ позволяет обеспечить экономическую, политическую и социальную целостность государства, их стабильность.

На государственном уровне должна быть обеспечена реализация принципов и норм, закрепленных в Конституции РФ, что относится к обязанностям государства и гарантирует стабильность общественного развития. В системе средств и государственных гарантий, обеспечивающих выполнение конституционно установленных ценностей, существенную роль играет создание и обеспечение механизма судебной защиты.

Конституционное правосудие представляет собой важное направление в общей системе судопроизводства. Особая роль в осуществлении конституционного правосудия отводится Конституционному Суду РФ. От эффективности осуществления конституционного правосудия находится в зависимости соблюдение положений Конституции РФ, устранение допущенных нарушений в конкретных случаях, реализуются и меры предупредительной, профилактической направленности.

Особый интерес в таком свете представляет исследование становления и развития конституционного правосудия в Российской Федерации. Формирование системы конституционного правосудия имеет некоторые особенности, которые свидетельствуют о постепенном становлении данного института, что позволяет определить имеющийся опыт и оценить современное состояние исследуемого вопроса.

Исследование развития конституционного правосудия в России, в том числе в части последовательных изменений по отношению к органам конституционного контроля, позволяет сделать выводы о наличии определенных закономерностей.

Вопросы развития конституционного правосудия находят отражение в трудах многих ученых, среди которых необходимо отметить следующих: С.А. Авакьян, Т.М. Боброва, Н.С. Бондарь, О.В. Брежнев, Е.С. Бутурлина, А.Е. Витевский, Н.В. Витрук, Г.А. Гаджиев, Е.В. Герасимова, В.Н. Демидов, В.А. Кряжков, Б.М. Лазарев, В.В. Лапаева, М.А. Митюков, И.А. Муравьев, С.А. Перчаткина,
А.А. Петров, К.А. Слесарева, Д.В. Фетищев, Е.В. Шевченко, Л.В. Юн и др.

Объект исследования - система общественных отношений, складывающихся по поводу конституционного правосудия в Российской Федерации (исторический аспект). Предмет исследования - нормативные правовые акты (действующие и имеющие историческое значение), положения юридической доктрины по вопросам, связанным со становлением и развитием конституционного правосудия в Российской Федерации.

\section{Шель работы}

Цель работы заключается в исследовании отдельных аспектов истории конституционного правосудия Российской Федерации.

\section{Метолы исслеАования}

В исследовании использованы общие методы научного познания, среди которых анализ, синтез, дедукция, исторический метод. Применяются и специально-юридические методы исследования: формально-юридический, метод толкования права.

\section{Обсужление}

Целесообразно определить существующие подходы к определению конституционного правосудия и специфику деятельности органов конституционного контроля, сложившиеся в настоящее время. Согласно ст. 118 Конституции РФ, правосудие в Российской Федерации осуществляется только судом, судебная власть осуществляется в том числе посредством осуществления конституционного правосудия [1].

По мнению В.Н. Демидова, конструкционное правосудие выступает: «важным фактором обеспечения принципов демократического правового государства, поддержания режима конституционной законности, укрепления общегосударственной системы защиты прав и свобод человека и гражданина» [2, с. 17]. Конституционное правосудие выполняет целый ряд функций, реализует важные направления государственной политики и конституционные принципы. Присутствует прямая связь уровня демократического развития государства и осуществления конституционного правосудия.

Несомненно, активное развитие конституционного правосудия в последние десятилетия не может умалять формирование концепций относительно необходимости создания новых подходов на дореволюционном этапе, а также изменения в государстве и создание со- 
ответствующей законодательной базы и в период советской власти, при принятии Конституций СССР.

Т.М. Боброва предлагает под организационно-правовой формой осуществления конституционного правосудия понимать: «совокупность судебных органов (органа) конкретного государства, наделенных определенным объемом властных полномочий для защиты Конституции, и видов (вида) судопроизводств для их осуществления с присущими этим органам структурно-организационными и функциональными особенностями строения и деятельности» [3, с. 10]

На сегодняшний день, высшим судебным органом конституционного контроля, исходя из ст. 1 ФКЗ «О Конституционном Суде Российской Федерации», выступает Конституционный Суд РФ [4]. Е.В. Герасимова высказывает позицию о преобладании в его деятельности регулятивной и правозащитной функций $[5$, с. 8]. В свою очередь, Р.Е. Карасев указывает на наличие в правозащитной функции Конституционного Суда РФ двух форм: прямой и косвенной [6, с. 11].

Действительно, осуществление конституционного правосудия непосредственно связано с деятельностью Конституционного Суда, деятельность которого имеет сравнительно не богатую историю (начал действовать с 1991 г.) и создан данный орган был только в последние годы существования советской власти, о чем более подробно пойдет речь далее. В системе конституционного правосудия, Конституционным Судом РФ выполняются важные функции и к его деятельности предъявляются определенные требования:

- соблюдение требований конституционного процесса, судопроизводства;

- независимость от позиций иных органов государственной власти и их должностных лиц;

- связь в осуществлении судопроизводства с подачей жалобы (запроса) конкретным субъектом;

- отражение правовых позиций в двух формах постановление и определение;

- незамедлительное вступление последних в силу.

Н.А. Марокко придерживается следующей позиции относительно предназначения конституционного правосудия: «целью конституционного правосудия и конституционного судопроизводства служит обеспечение и защита верховенства Конституции РФ, обладающей высшей юридической силой, ее прямого действия на всей территории государства, то есть достижение и поддержание правового режима конституционности» [7, с. 7]. С указанной позицией следует согласиться в полной мере.

Конституционное правосудие предполагает деятельность уполномоченных органов государства, на- правленную на рассмотрение и разрешение вопросов о соответствии нормативных правовых актов различного уровня Конституции РФ, разрешение споров конституционного значения. Федеративное устройство определяет специфику построения конституционного правосудия, в рамках которого учитываются как общие интересы федерации, так и интересы ее отдельно взятых субъектов.

Соответственно, исходя из сложившихся в современный период подходов, можно говорить о реализации в конституционном правосудии важных функций, позволяющих реализовать единовременно правозащитную, регулирующую, профилактическую и иные важные функции для общества и государства.

Становление и развитие конституционного правосудия в отечественной истории правовой науки, имеет определенные истоки формирования и предпосылки. Среди ученых отсутствует единое мнение по поводу периодизации в истории конституционного правосудия.

А.Е. Витевский предлагает подход, который «носит комплексный характер и отражает процессы, происходившие в сфере правовой охраны конституции, конституционного правосудия как на уровне всей нашей страны, так и на уровне ее субъектов. В связи с этим предлагаем выделить два основных периода: первыйпериод теоретических идей, практических решений, предшествовавших созданию правосудия в России (конец XVII в.- конец 80-х годов XX в.); второй - период практического, реального создания конституционного правосудия и его функционирования в России (с 1990 г. по настоящее время)» [8, с. 8-9].

Дореволюционный период (до 1917 г.) характеризуется монархическим строем, а период 1917-1991 гг. является социалистическим. Последний, свидетельствует о принятии конкретных мер, направленных на создание и работу системы конституционного правосудия.

Н.Р. Плиев, А.К. Хадиков приходят к выводу о целесообразности использования по отношению к развитию истории конституционного правосудия периодизации, предложенной М.А. Митюковым:

1. первоначальное зарождение идей конституционного правосудия (XIX - начало XX вB.);

2. реализация Верховным Судом СССР полномочий по конституционному надзору (1924-1933 гг.);

3. реализация конституционного контроля в «квазипарламентских» формах (1936-1987 гг.);

4. возникновение специализированного конституционного надзора (1988-1991 гг.);

5. учреждение Конституционного Суда РФ (с 1991 г. по настоящее время) [9, с. 233]. 
Представляется, что в общем плане, в истории конституционного правосудия следует выделить такие этапы как дореволюционный, советский и современный. В дореволюционный период формировались подходы относительно идей конституционного правосудия. Возникновение идей по поводу конституционного правосудия датируется еще временем правления Екатерины II, с опорой на опыт европейских стран (в том числе Франции). В частности, перспективной идеей выступало создание специализированного конституционного органа, а также расширение полномочий Сената. Основная идея заключалась в возможности проверки законов на предмет соответствия определенным требованиям.

Далее, идеи о развитии конституционного отражения находят в трудах многих ученых и общественных деятелей. Так, М.М. Сперанский занимается подготовкой проекта Конституции (1808г.), в котором было указано на возможность проверки законодательных документов, которые оспаривались. Неоднократно высказывались идеи о развитии идей конституционного контроля и надзора (А.П.Бестужев-Рюмин, П.И.Пестель). Идеи конституционного контроля находит отражение и в дальнейших проектах Конституции (1894 г., 1905 г.).

С.Т. Артемова также придерживается позиции о том, что на дореволюционном этапе находят отражение вопросы конституционного правосудия были представлены как в трудах общественных деятелей своего времени, так и поставлены в нормативных правовых актах и конституционных проектах. Развитие научных представлений в данный период направлен от конституционного надзора к конституционному контролю в виде судопроизводства, от предварительного конституционного контроля к последующему [10, с. 95-96].

В целом, возможностям конституционного контроля и методам их применения в Российской Империи уделялось не малое внимание, что находит отражение в работах ученых-правоведов того времени (М.М. Ковалевский, С.А. Котляревский, М.А. Рейснер и др.). В конце дореволюционного периода, была накоплена весьма обширная научная база относительно идей и концепций конституционного правосудия.

Существенные изменения в развитии подходов к пониманию конституционного правосудия связаны с Октябрьской революцией 1917 г. и образованием СССР. Происходит внесение существенных изменений во все сферы жизнедеятельности общества и государства, происходят масштабные изменения в законодательной базе. Идеи о конституционном контроле потеряли на некоторое время свою актуальность. Однако, в 1918 г. принимается первая советская Конституция [11]. Принятие Конституции РСФСР 1918 г. было существенным шагом вперед в сфере развития конституционализма.

В период 1924-1933 гг. следует говорить о развитии мер конституционного контроля, связанной с осуществлением соответствующей деятельности Верховным Судом СССР. Последний был наделен многими функциями, Верховный Суд СССР на основании Постановления Президиума ЦИК СССР от 23.11.1923 был наделен компетенцией по составлению консультативных заключений в части проверки конституционности положений нормативных правовых актов союзного уровня [12].

За Верховным Судом СССР была закреплена возможность осуществлять деятельность в сфере конституционного контроля на основании собственной инициативы. Высказывались разные позиции относительно целесообразности наделения данного органа полномочиями в сфере конституционного контроля.

В советский период следует отметить принятие нескольких Конституций, в том числе Конституции СССР 1924 г. [13] и Конституции СССР 1936 г. [14]. В рамках которых, конкретизация норм об осуществлении конституционного контроля, активного развития не получает. Существенные изменения в исследуемом направлении отсутствуют.

Следует согласиться с позицией Е.В.Грызуновой, А.Д. Точина, что в процессе обсуждения проектов Конституции СССР 1924 г. и Конституции СССР 1936 г. поднимался вопрос о расширении полномочий Верховного Суда СССР в сфере конституционного контроля с целью поддержания, равно как и укрепления уровня законности [15. с. 52].

Достаточно продолжительное время функции конституционного контроля осуществлялись Верховным Судом СССР, в соответствии со сложившейся политикой. К компетенции было отнесено право толковать законы и отменять нормативные акты (союзного и республиканского значения), противоречащие Конституции СССР.

По мнению О.В.Брежнева, преобладает позиция о предпочтительности осуществления конституционного надзора во внесудебном порядке во взаимосвязи с недостатками его правовой регламентации, предопределили дальнейшие события [16, с. 183].

В конечном итоге полномочия Верховного Суда СССР в сфере конституционного контроля были сокращены и переданы прокуратуре СССР (1936 г.). Подобная 
тенденция объясняется тем, что Прокурор СССР обладал исключительными полномочиями по реализации мер конституционного надзора. Таким образом, контрольные и надзорные полномочия были переданы одному государственному органу (прокуратуре).

Кроме прочего, полная передача полномочий по осуществлению конституционного контроля и надзора органам прокуратуры связана с развитием идей конституционного правосудия в контексте существовавших идеологических ценностей.

В целом, реализация функций по осуществлению конституционного контроля не имела системного подхода и признаков регулярности. Однако, перед наукой и практикой назрела необходимость в повышенном внимании к мерам конституционного контроля в целом, разработке мер по осуществлению конституционного правосудия.

Далее, существенным значением в сфере развития конституционного права становится принятие Конституции СССР 1977 г. [17]. В процессе обсуждения проекта Конституции 1977 г. поднимался вопрос о необходимости создания специальной конституционной коллегии (комиссии), о создании Конституционного Суда. На практике, они не нашли отражения в положениях Конституции СССР 1977 г. В последующем внесены изменения и дополнения в Конституцию СССР 1977 г. (от 01.12.1989 г. в ст. 125), связанные с учреждением Комитета конституционного надзора СССР.

Создание указанного органа имело существенное значение для развития системы конституционного правосудия. В 1989 г. принимается специализированный Закон «О конституционном надзоре в СССР» [18]. K полномочиям данного органа конституционного правосудия были отнесены различные аспекты, в том числе проверка конституционности действующих законов СССР, законопроектов, актов Генерального прокурора, Главного государственного арбитра и ряд других.

Н.В. Григорьева указывает на схожесть Комитета конституционного надзора СССР с моделью конституционного контроля во Франции - Конституционным Советом Франции. Данный орган, по мнению ученой, характеризуется как квазисудебный орган, в связи с рекомендательным характером его решений [19, с. 8-9].

Представляется, что именно наличие квазисудебного характера исследуемого органа поставило под вопрос его эффективность и повлияло на обозначение потребности в дальнейшем реформировании органов конституционного контроля.
Комитет конституционного надзора СССР просуществовал не продолжительное время и закончил свою деятельность в 1991 г. в связи с распадом СССР. В историческом аспекте, его появление сыграло существенную роль в дальнейшем развитии органов конституционного правосудия.

Отдельно стоит затронуть вопрос об истории развития Конституционного Суда РФ. Возникновение идей о необходимости создания данного органа датируется периодом принятия Конституции 1977 г. и обсуждения ее проекта. После внесения изменений в Конституцию СССР 1977 г. (от 15.12.1990 г.), впервые можно увидеть упоминание о Конституционном Суде. В частности, определено, что порядок его деятельности должен быть урегулирован в специализированном законе.

В 1991 г. принимается Закон РСФСР «О Конституционном Суде РСФСР» [20], на его основании осуществляется деятельность. С.А. Авакьян отмечает, что крупные изменения относительно Конституционного Суда РФ, про изошли при реформе 21.04.1992 г., усилившие его роль в государстве [21].

Однако, 7.10.1993 г. Б.Н. Ельцин приостанавливает его деятельность. Новый этап развития Конституционного Суда, уже Российской Федерации, связан с принятием в 1993 г. Конституции РФ, В ст. 125 которой были заложены правовые основы его деятельности. В 1994 г. принимается ФКЗ «О Конституционном Суде Российской Федерации», действующий вплоть до настоящего времени. В его рамках определяются особенности деятельности, конкретизируются многие важные положения.

Целесообразно отметить нововведения, появившиеся в деятельности Конституционного Суда РФ, в сравнении с ранее действовавшим законодательством:

- сформированы новые подходы к формированию судей (в сторону увеличения с 15 до 19, а на сегодняшний день законом установлено иное количество - 11 судей);

- утрачено право рассматривать дела по собственной инициативе;

- становится недопустимым дача оценки конституционности действий определенных должностных лиц, партий.

Соответственно, в настоящее время, Конституционный Суд РФ осуществляет проверку исключительно нормативных правовых актов на основании запросов или жалоб. С 1995 г. деятельность данного органа была полностью возобновлена. В настоящее время, Постановления Конституционного Суда РФ затрагивают самые разнообразные сферы общественных отношений. 
В положения ФКЗ «О Конституционном Суде Российской Федерации», были внесены ряд изменений (2009, 2010, 2014, 2015, 2020, 2021), связанные со структурой данного органа, сроков полномочий, процедуры конституционного судопроизводства, относительно предварительного конституционного контроля законодательных актов, роли в исполнении решений межгосударственных органов и др.

Следует согласиться с позицией, которую высказывает Н.С. Бондарь: «Конституционный Суд РФ по праву стал символом утверждения в нашей стране демократических институтов нового конституционного строя в соответствии с основополагающими ценностями современного конституционализма» [22, с. 35]. Как ранее уже было отмечено, особенности формирования конституционного правосудия тесно связаны с идеологическим обеспечением, формированием общественных взглядов.

Вместе с развитием Конституционного Суда РФ происходило и развитие конституционных (уставных) судов субъектов РФ. Указанному направлению уделялось внимание в научной литературе. Так, С.Н. Школа отмечает непоследовательность в истории формирования регионального законодательства об органах конституционной (уставной) юстиции, выделяет период наиболее интенсивного развития регионального законодательства об органах конституционного (уставного). По мнению ученого, такой период длился с 1997 г. (принятие Ф3 «О судебной системе Российской Федерации») по 2001 г. (формирования практики относительно компетенции и ее пределов) [23, с. 8-9].

В 2020 г. принимается решение об упразднении конституционных (уставных) судов на основании введения в действие ФКЗ «О внесении изменений в отдельные федеральные конституционные законы» [24]. Так, конституционные (уставные) суды субъектов РФ должны быть упразднены не позднее 1.01.2023 г. Соответственно, в настоящее время уже не производится принятие новых дел к производству, а также назначение новых судей. Решение об упразднении данных органов конституционного контроля обусловлено малым количеством рассматриваемых ими дел при значительных затратах бюджетных средств, а также существовании в ограниченном количестве субъектов.

И.М. Евлоев придерживается позиции о том, что было необходимо не упразднять конституционные (уставные суды), а более четко определить их предназначение в государственной системе и цели существования. Именно небольшой объем полномочий конституционных судов и недостаточное четкое их разграничение с полномочиями Конституционного Суда
РФ и судов общей юрисдикции, привело их к не востребованности [25, с. 146].

Несмотря на то, что не во всех субъектах РФ действовали конституционные (уставные) суды, упразднение данной системы несет в себе некоторые неудобства. Так, более сложной становится процедура проверки на предмет соответствия Конституции РФ местного законодательства.

За субъектами РФ сохранено право по принятию решения о создании конституционных (уставных) советов, действующих при законодательных (представительных) органах государственной власти субъектов РФ. Механизм их деятельности, система полномочий, на законодательном уровне не определен. Ликвидация возможности как функционирования действующих конституционных (уставных) судов, так и учреждения новых органов, не устраняет проблему исполнения региональных конституций и уставов. Необходимо совершенствование механизма деятельности органа, наделенного контрольными полномочиями.

\section{Выво $\triangle \mathrm{b}$}

По результатам исследования, был сделан ряд выводов и предложений:

1. Конституционное правосудие предполагает деятельность уполномоченных органов государства В лице Конституционного Суда РФ, направленную на рассмотрение и разрешение вопросов о соответствии нормативных правовых актов различного уровня Конституции РФ, разрешение споров конституционного значения. К последним, относятся дела о проверке соответствия оспариваемого нормативного правового акта Конституции РФ и требованиям действующего законодательства различного уровня, а также не вступивших в силу международных договоров РФ. Также к компетенции Конституционного Суда РФ относится разрешения споров о компетенции:

- между федеральными органами государственной власти;

- между органами государственной власти РФ и органами государственной власти субъектов $P \Phi$;

- между высшими государственными органами субъектов РФ.

2. Посредством конституционного правосудия осуществляется регулирование наиболее значимых общественных отношений, имеющих связь с основами конституционного строя, правами человека и гражданина, системой взаимодействия в системе «личность - общество - государство», порядком деятельности госу- 
дарственной и муниципальной власти, а также иными основополагающими положениями, вытекающими из норм Конституции РФ.

3. Единая периодизация об истории конституционного правосудия на сегодняшний день не сформирована, учеными высказываются различные позиции относительно периодов развития. В общем плане, следует говорить о нескольких этапах в истории конституционного правосудия: дореволюционный, советский и современный.

4. В дореволюционный период был сформирован целый ряд идей, концепций о необходимости конституционного контроля и надзора. Появляются фундаментальные труды отечественных ученых-правоведов. Данный этап следует отметить как формирующий предпосылки для развития системы конституционного правосудия далее.

5. В советский период было принято несколько Конституций (1918 г., 1924 г., 1936 г., 1977 г.). Изменялись подходы к наделению полномочиями по конституционному контролю различных органов. В начальном периоде деятельности советской власти, подобные функции выполнял Верховный Суд СССР, прокуратура СССР. Лишь в 1970-1980 гг. возник вопрос о необходимости создания специализированных органов. На основании чего, появляется Комитет конституционного надзора СССР, далее Конституционный Суд РСФСР.

6. Современный этап развития связан с принятием Конституции РФ 1993 г. Конституционный Суд РФ появляется на основании своего предшественника Конституционного Суд РСФСР. При этом происходят отдельные организационные преобразования. Существенно изменились подходы к рассмотрению дел Конституционным Судом РФ. Так, отменено право рассматривать дела по собственной инициативе, основанием для деятельности становится поступление запроса или жалобы. Кроме того, конституционность действий определенных должностных лиц, партий не относится к предмету конституционного контроля.

7. Прослеживаются определенные закономерности в части развития органов конституционного правосудия в России. Установлено, что после принятия Конституции СССР 1924 г. и Конституции СССР 1936 г., согласно сложившейся политике, полномочия в сфере конституционного контроля принадлежали Верховному Суду СССР. К его компетенции было отнесено право толковать законы и отменять нормативные акты (союзного и республиканского значения), противоречащие Конституции СССР.

Далее, полномочия Верховного Суда СССР в сфере конституционного контроля были сокращены и пере- даны прокуратуре СССР (1936 г.). За органами прокуратуры закреплены функции по осуществлению конституционного контроля и конституционного надзора. Связано это в том числе и с тем, что Прокурор СССР обладал исключительными полномочиями по реализации мер конституционного надзора. Идеологические воззрения общества не свидетельствовали о возможности применения в полной мере концепции о разделении властей.

Принятие Конституции РСФСР 1977 г. повлияло на проводимую политику в конституционной сфере. В 1989 г. создан Комитет конституционного надзора СССР, решения которого обладали рекомендательным характером, в связи с чем возник вопрос об эффективности его деятельности и необходимости существования (упразднен в 1991 г.). Появление данного органа сыграло существенную роль в развитии и реформировании органов конституционного контроля.

На смену последнего пришел Конституционный Суд РФ, полномочия которого изменялись с течением времени. В том числе, и под влиянием принятия Конституции РФ 1993 г. Значительную роль сыграло усиление демократических принципов, направленность на неукоснительное соблюдение прав и свобод человека и гражданина, а также иные тенденции, связанные в том числе и с международным регулированием различных вопросов.

8. Затронут вопрос истории конституционных (уставных) судов субъектов РФ. Наибольшее внимание данному вопросу уделялось с позиции законодательного регулирования в период 1997-2001 г. В 2020 г. было принято решение об упразднении конституционных (уставных) судов. Последние, действовали не во всех субъектах РФ, тем не менее, упразднение конституционных (уставных) судов оставляет открытыми отдельные вопросы.

В частности, за субъектами РФ сохранено право по принятию решения о создании конституционных (уставных) советов, действующих при законодательных (представительных) органах государственной власти субъектов РФ. Необходимо создание законодательной основы для механизма их деятельности, определения системы полномочий, роли в исполнении региональных конституций и уставов.

Полученные результаты могут быть полезны для применения в учебно-педагогических и методических целях, для теоретического осмысления актуальных вопросов в сфере совершенствования системы конституционного правосудия. 


\section{ЛИТЕРАТУРА}

1. Конституция Российской Федерации (принята всенародным голосованием 12.12.1993 с изменениями, одобренными в ходе общероссийского голосования 01.07.2020) // Официальный интернет-портал правовой информации http://www.pravo.gov.ru, 04.07.2020.

2. Демидов В.Н. Конституционное правосудие субъектов Российской Федерации в общегосударственной системе защиты прав и свобод человека и гражданина: методология, теория, практика: автореферат дис. ... доктора юридических наук. Москва, 2017. 68 с.

3. Боброва Т.М. Организационно-правовая форма осуществления конституционного правосудия в Российской Федерации: становление, развитие и проблемы совершенствования: автореферат дис. ... кандидата юридических наук. Москва, 2015. 32 с.

4. Федеральный конституционный закон от 21.07.1994 № 1-ФКЗ (ред. от 01.07.2021) «0 Конституционном Суде Российской Федерации» // Собрание законодательства РФ. 25.07.1994. № 13. Ст. 1447.

5. Герасимова Е.В. Роль Конституционного Суда Российской Федерации в системе судебной защиты прав и свобод человека и гражданина: дис. ... кандидата юридических наук. Санкт-Петербург, 2011. 178 с.

6. Карасев Р.Е. Осуществление Конституционным Судом Российской Федерации защиты прав и свобод человека и гражданина: дис. ... кандидата юридических наук. Тюмень, 2016. 291 с.

7. Марокко Н.А. Функция защиты основных прав и свобод человека и гражданина в контексте реализации полномочий Конституционного Суда Российской Федерации: автореферат дис. ... кандидата юридических наук. Москва, 2009. 22 с.

8. Витевский А.Е. Становление конституционного правосудия в России: автореферат дис. ... кандидата юридических наук. Москва, 2008. 31 с.

9. Плиев Н.Р., Хадиков А.К. Основные этапы возникновения и развития института конституционного правосудия Российской Федерации // Балтийский гуманитарный журнал. 2017. Т. 6. № 2 (19). С. 233-236.

10. Артемова С.Т. Развитие идей о конституционном правосудии в России в дореволюционный период // Правовая политика и правовая жизнь. 2010. № 1. C. 88-96.

11. Конституция (Основной Закон) Российской Социалистической Федеративной Советской Республики (принята V Всероссийским съездом Советов 10.07.1918) // СУ РСФСР. 1918. № 51. Ст. 582.

12. Постановление Президиума ЦИК СССР от 23.11.1923 «Положение о Верховном Суде Союза Советских Социалистических Республик» // Вестник ЦИК, СНК и СТО СССР. 1923. № 10. Ст. 311.

13. Постановление II Съезда Советов СССР от 31.01.1924 «06 утверждении Основного Закона (Конституции) Союза Советских Социалистических Республик» // Вестник ЦИК, СНК и СТО СССР. 1924. № 2. СТ. 24.

14. Конституция (Основной Закон) Союза Советских Социалистических Республик (утв. Постановлением Чрезвычайного VIII Съезда Советов СССР от 05.12.1936) // Известия ЦИК СССР и ВЦИК. № 283. 06.12.1936.

15. Грызунова Е.В., Точин А.Д. Становление и развитие конституционного правосудия в Российской Федерации // Юридическая наука: история и современность. 2018. № 12. С. 50-57.

16. Брежнев 0.В. Верховный Суд СССР как орган конституционного надзора в 1924-1933 гг. // Известия Юго-западного государственного университета. 2016. № 4 (67). С. 177-184.

17. Конституция (Основной Закон) Союза Советских Социалистических Республик (принята ВС СССР 07.10.1977) // Ведомости ВС СССР. 1977. № 41. Ст. 617.

18. Закон СССР от 23.12.1989 «0 конституционном надзоре в СССР» // Свод законов СССР. Т. 1, С. 44-3. 1990.

19. Григорьева Н.В. Исторические этапы формирования органов конституционного контроля в России // Вестник Томского государственного университета. 2020. № 65. C. 5-12.

20. Закон РСФСР от 12.07.1991 № 1599-1 «0 Конституционном Суде РСФСР» // Ведомости СНД и ВС РСФСР. 25.07.1991. № 30. Ст. 1017.

21. Авакьян С.А. Конституция России: природа, эволюция, современность. М.: Сашко, 2000. URL: https://constitution.garant.ru/science-work/ modern/1776651/chapter/948c9c0734b6e944a4727660f2d5a027/ (дата обращения: 10.10.2021).

22. Бондарь Н.С. Конституционное правосудие и развитие конституционной юриспруденции в России // Журнал российского права. 2011. № 10 (178). C. $35-46$.

23. Школа С.Н. Конституционное правосудие в субъектах Российской Федерации: теоретический и историко-правовой анализ: автореферат дис. .... кандидата юридических наук. Краснодар, 2007. 32 с.

24. Федеральный конституционный закон от 08.12.2020 № 7-ФКЗ «0 внесении изменений в отдельные федеральные конституционные законы» // Российская газета. № 280. 11.12.2020.

25. Евлоев И.М. Ликвидация конституционных (уставных) судов субъектов РФ: закономерность или ошибка? // Актуальные проблемы российского права. 2020. Т. 15. № 10 (119) С. 141-150.

(c) Савастлеев Андрей Андреевич ( Daytona@konstantah.com )

Журнал «Современная наука: актуальные проблемы теории и практики» 